Article

\title{
Phytoremediation Opportunities with Alimurgic Species in Metal-Contaminated Environments
}

\author{
Marianna Bandiera, Cristian Dal Cortivo, Giuseppe Barion, Giuliano Mosca \\ and Teofilo Vamerali * \\ Department of Agronomy, Food, Natural Resources, Animals and the Environment, University of Padova, \\ Viale dell'Università 16, 35020 Legnaro-Padova, Italy \\ * Correspondence: teofilo.vamerali@unipd.it; Tel.: +39-049-8272861
}

Academic Editor: Tiziano Gomiero

Received: 8 January 2016; Accepted: 5 April 2016; Published: 12 April 2016

\begin{abstract}
Alimurgic species are edible wild plants growing spontaneously as invasive weeds in natural grassland and farmed fields. Growing interest in biodiversity conservation projects suggests deeper study of the multifunctional roles they can play in metal uptake for phytoremediation and their food safety when cultivated in polluted land. In this study, the responses of the tap-rooted perennial species Cichorium intybus L., Sonchus oleracerus L., Taraxacum officinale Web., Tragopogon porrifolius L. and Rumex acetosa $\mathrm{L}$. were studied in artificially-highly $\mathrm{Cd}$-Co-Cu-Pb-Zn-contaminated soil in a pot-scale trial, and those of T. officinale and R. acetosa in critical open environments (i.e., landfill, ditch sediments, and sides of highly-trafficked roads). Germination was not inhibited, and all species showed appreciable growth, despite considerable increases in tissue metal rates. Substantial growth impairments were observed in C. intybus, T. officinale and T. porrifolius; R. acetosa and S. oleracerus were only marginally affected. Zn was generally well translocated and reached a high leaf concentration, especially in T. officinale $\left(\sim 600 \mathrm{mg} \cdot \mathrm{kg}^{-1}\right.$. dry weight, DW), a result which can be exploited for phytoremediation purposes. The elevated $\mathrm{Cd}$ translocation also suggested applications to phytoextraction, particularly with $C$. intybus, in which leaf $C d$ reached $\sim 16 \mathrm{mg} \cdot \mathrm{kg}^{-1}$. DW. The generally high root retention of $\mathrm{Pb}$ and $\mathrm{Cu}$ may allow their phytostabilisation in the medium-term in no-tillage systems, together with significant reductions in metal leaching compared with bare soil. In open systems, critical soil $\mathrm{Pb}$ and $\mathrm{Zn}$ were associated with heavily trafficked roadsides, although this was only seldom reflected in shoot metal accumulation. It is concluded that a community of alimurgic species can serve to establish an efficient, long-lasting vegetation cover applied for phytoremediation and reduction of soil metal movements in degraded environments. However, their food use is not recommended, since leaf $\mathrm{Cd}$ and $\mathrm{Pb}$ may exceed EU safety thresholds.
\end{abstract}

Keywords: alimurgic species; food safety; trace elements; phytoremediation; tap-rooted plants

\section{Introduction}

Trace elements, acting as micro-nutrients or environmental contaminants according to their type and abundance, generally occur at very low rates in both soils and plants. $\mathrm{Cd}$ and $\mathrm{Pb}$ are hazardous toxic metals for both plants and humans, and crop cultivation should reduce their entry into the food chain. $\mathrm{Pb}$ has severe effects on human health, as its carcinogenic potential can already be detected at low rates in blood $\left(<0.2 \mathrm{mg} \cdot \mathrm{L}^{-1}\right)$, causing immune function impairment and altering enzyme activities [1-3]. Cd is also carcinogenic for many organs, so that its safe daily intake should be kept $<30 \mu \mathrm{g}[4,5]$. Other metals, such as $\mathrm{Cu}, \mathrm{Zn}$ and $\mathrm{Co}$, play an essential role in living organisms, but may also become toxic above specific values in both plants and animals. $\mathrm{Zn}$ and $\mathrm{Cu}$ are important co-factors of many enzymes, the former mainly involved in nucleic acid and protein synthesis, and the latter in energy production and neurotransmitter synthesis; Co is a core constituent of vitamin 
B12 [6,7]. Daily Zn intake within ranges of 50-300 and 150-200 mg causes chronic and acute toxicity, respectively, whereas 110 and $400 \mathrm{mg} \cdot \mathrm{kg}^{-1}$ body weight have been identified as $\mathrm{LD}_{50}$ for $\mathrm{Cu}^{+2}$ and $\mathrm{Cu}$ nanoparticles, respectively [8,9]. Excessive $\mathrm{Cu}$ and $\mathrm{Co}$ intake results in the production of highly reactive oxygen species, causing oxidation of membrane lipids, proteins and nucleic acids $[7,10]$.

As soil metal contamination is rapidly increasing worldwide, mainly because of human activities, phytomanagement of polluted land is becoming an environmentally sustainable and cost-effective option that can also produce biomass and energy as secondary utilities [11]. In phytoextraction, the main challenge is to combine high shoot metal contents with elevated biomass yield, although integrated phytomanagement technologies also include metal stabilisation in plant roots and soil [12]. The artificial enrichment of plant foods with micronutrients, known as biofortification, is closely linked to phytoextraction, as both aim at increasing metal bioavailability, uptake and translocation, although selective uptake of non-toxic elements is required for food uses $[13,14]$.

In the last few decades, several wild plants collected from mining areas, mainly belonging to Brassicaceae species, have been identified as efficient metal hyperaccumulators [15]. Some Asteraceae and Polygonaceae species growing spontaneously as invasive weeds on natural and farmed land, which are considered medical or edible alimurgic species, also accumulate high above-ground levels of toxic elements, thanks to efficient root-to-shoot translocation. Most of them combine high adaptability to marginal soils with good shoot biomass, and many are metal indicator or hyperaccumulator species [16-18]. Their leaves, consumed fresh or boiled, occasionally together with roots, are also known for their depurative, diuretic and cough suppressant properties. Most of these species have in fact been intensively used as alimurgic herbs in the past, being rich in minerals, vitamins and fibre, but they have been almost completely abandoned in the last few decades in industrialised countries. Recent renewed interest in biodiversity conservation and seed collection projects suggests that their metal uptake ability should be explored to verify whether phytoremediation application is feasible and to establish safety in food uses when grown in critical environments.

In this study the shoot and root growth potential, metal uptake and translocation at the flowering stage of some pot-cultivated Asteraceae and Polygonaceae alimurgic species were investigated in artificially highly $\mathrm{Cd}-\mathrm{Co}-\mathrm{Cu}-\mathrm{Pb}-\mathrm{Zn}$-contaminated soil. The same species were also collected in open fields from potentially contaminated sites during spring. According to metal compartmentalisation in plant organs, their phytoextraction/phytostabilisation potential was evaluated, together with the risks for food uses. Based on metal leaching, this research also aimed at predicting the environmental benefits deriving from a vegetation cover compared with uncultivated bare soil.

\section{Experimental Section}

\subsection{Pot Trial Set-Up}

Common dandelion (Taraxacum officinale Web.), wild chicory (Cichorium intybus L.), common sowthistle (Sonchus oleraceus L.), salsify (Tragopogon porrifolius L.) and garden sorrel (Rumex acetosa L.) were grown in a silty-loam soil, at $\mathrm{pH}$ 8.4, artificially contaminated with $\mathrm{Cd}, \mathrm{Co}, \mathrm{Cu}, \mathrm{Pb}$ and $\mathrm{Zn}$. The soil was collected from the experimental farm of the University of Padova at Legnaro (NE Italy). After air-drying and grinding, it was mixed with fine sand $(1: 1 \mathrm{w} / w)$ and contaminated with a metal (as sulphate) solution at a rate of 1:10 v/w. The soil was carefully homogenised, and periodically mixed and wetted for 6 months before being used in the experiment. The final metal concentrations exceeded the Italian Guideline Values (IGV) for agricultural uses by $\sim 2 \times$ for $\mathrm{Cd}, \mathrm{Co}$ and $\mathrm{Pb}, 4 \times$ for $\mathrm{Cu}$, and $6 \times$ for Zn (Table 1).

The plants were grown in greenhouses in 1-L PVC pots (height $20 \mathrm{~cm}$; diameter $8 \mathrm{~cm}$ ), following a completely randomised experimental design with three replicates, comparing contaminated vs. uncontaminated reference soils. In order to collect the leachate, 1.5-L opaque sealed PVC bottles were connected to the pot base with black tubing. Sowing took place at the end of October 2011 at soil field capacity, with five seeds per pot. Plants were early thinned to three per pot and regularly 
watered with a 50\% diluted Hoagland solution throughout the experiment. The trial also included both contaminated and uncontaminated uncultivated controls $(n=3)$, which were watered with the same amount of nutrient solution and used as absolute references. A total irrigation volume of $4.9 \mathrm{~L}$ was applied to each pot in the trial.

Table 1. Pseudo-total and diethylenetriaminepentaacetic acid (DTPA) extractable metal concentrations $\left(\mathrm{mg} \cdot \mathrm{kg}^{-1} \mathrm{DW}, n=3\right)$ in contaminated $v$ s. reference uncontaminated soils in pot trial.

\begin{tabular}{cccccccc}
\hline \multirow{2}{*}{ Metal } & \multirow{2}{*}{ IGV (A) } & \multicolumn{2}{c}{ Pseudo-Total (B) } & \multicolumn{2}{c}{ (B/A) } & \multicolumn{2}{c}{ DTPA Extractable } \\
\cline { 3 - 7 } & & Reference & Contaminated & Reference & Contaminated & Reference & Contaminated \\
\hline $\mathrm{Cd}$ & 2 & $<0.20$ & 3.66 & $<0.10$ & 1.83 & $0.09(45 \%)$ & $3.05(83.3 \%)$ \\
$\mathrm{Co}$ & 20 & 5.54 & 36.8 & 0.28 & 1.84 & $0.05(0.9 \%)$ & $4.82(13.1 \%)$ \\
$\mathrm{Cu}$ & 120 & 20.5 & 496 & 0.17 & 4.13 & $4.4(21.5 \%)$ & $226(45.5 \%)$ \\
$\mathrm{Pb}$ & 100 & 12.5 & 163 & 0.13 & 1.63 & $2.93(23.5 \%)$ & $40.9(25.1 \%)$ \\
$\mathrm{Zn}$ & 150 & 46.7 & 906 & 0.31 & 6.04 & $1.54(3.3 \%)$ & $368(40.6 \%)$ \\
\hline \multicolumn{3}{c}{ IGV: Italian Guideline Values for “Green public, private and residential areas" (Italian Legislative Decree } \\
\multicolumn{3}{l}{ 152/2006). In brackets: DTPA extractable metal fraction (\% of pseudo-total). }
\end{tabular}

During the growing cycle, leaf chlorophyll content was measured with a SPAD 502 chlorophyll meter (Konica-Minolta, Hong Kong) on fully developed leaves (six leaves per replicate) in early May and mid-June 2012. Plant harvest took place at mid-June, when S. oleraceus and C. intybus flowered, and during the vegetative phase of the other species. Stems (if present), leaves and tap-roots were collected and weighed separately (after $24 \mathrm{~h}$ oven-drying at $105^{\circ} \mathrm{C}$ ). Fibrous roots were separated from the main axes after soil washing and flotation on a $500 \mu \mathrm{m}$ mesh sieve from two main layers $(0-10$ and $10-20 \mathrm{~cm}$ ), following the procedure of [19]. Root length was measured by automatic analysis (KS300 software, Carl Zeiss Vision GmbH, München, Germany) of 1-bit 400 DPI TIFF root images acquired through a flatbed scanner (Epson Expression 10000XL, Epson.com: Suwa, Japan), according to the method of [20].

\subsection{Soil and Leachate Analyses}

Soil pseudo-total metal concentrations were revealed before sowing on $1 \mathrm{~g} \cdot \mathrm{dry}$ weight (DW) $<2 \mathrm{~mm}$ sieved samples (analyses in triplicate). After microwave acid-digestion by EPA method 3051 [21] (Mileston ETHOS 900, Bergamo, Italy), samples were filtered through $0.45 \mu \mathrm{m}$ cellulose acetate (CA) filters, diluted to $50 \mathrm{~mL}$, and analysed by Inductively Coupled Plasma Optical Emission Spectroscopy (ICP-OES) (SPECTRO CirOS Vision EOP, SPECTRO Analytical Instruments GmbH \& Co. KG, Kleve, Germany). A certified reference material (ERM-CC141, JRC-IRMM, Geel, Belgium) was used to ensure measurement accuracy.

During the trial, the dynamics of bioavailable soil $\mathrm{Cd}, \mathrm{Co}, \mathrm{Cu}, \mathrm{Pb}$ and $\mathrm{Zn}$ were monitored over time in uncultivated references (both contaminated and uncontaminated) by periodic sampling, according to [22]. Metal extraction was performed on $50 \mathrm{~g}$ samples of homogenised dried substrate in a $100 \mathrm{~mL}$ solution of diethylenetriaminepentaacetic acid (DTPA, $1.97 \mathrm{~g} \cdot \mathrm{L}^{-1}$ ), calcium chloride bihydrate $\left(1.46 \mathrm{~g} \cdot \mathrm{L}^{-1}\right)$, and triethanolamine $\left(14.92 \mathrm{~g} \cdot \mathrm{L}^{-1}\right), \mathrm{pH} 7.3$, and shaken for $2 \mathrm{~h}$ (60 rotations per $\mathrm{min})$. Extracts were centrifuged for $5 \mathrm{~min}$. at $2599 \times \mathrm{g}$ and metal concentrations revealed by ICP-OES.

At the end of the trial, the amount of percolated water was measured and metal concentrations revealed by ICP-OES on filtered (0.45- $\mu \mathrm{m} \mathrm{CA})$ and acidified $\left(\mathrm{HNO}_{3} 65 \% v / v\right.$-Merck KGaA Germany) $10 \mathrm{~mL}$ samples. The quantity of metal leachate was calculated from multiplication of water volume by individual element concentration.

\subsection{Plant Analysis}

Metal concentrations in plant tissues were revealed on $\sim 0.4 \mathrm{~g}$ of oven-dried ground samples of shoots and tap roots, separately. Samples were added with $7 \mathrm{~mL} \mathrm{HNO}_{3}(65 \% v / v)$ and $1 \mathrm{~mL} \mathrm{H}_{2} \mathrm{O}_{2}(30 \%$ 
$v / v$ ) and microwave acid-digested by EPA method 3052 [23]. The samples were then diluted to $25 \mathrm{~mL}$ with distilled water, filtered (0.45- $\mu \mathrm{m} \mathrm{CA})$ and analysed by ICP-OES. Certified reference materials (ERM-CD281 and BRC-402, JRC-IRMM, Geel, Belgium) were used to ensure measurement accuracy. Metal removals were calculated by multiplying shoot and root weights by tissue metal concentrations.

The metal bioconcentration factor (BCF; root-to-soil concentration ratio), biological absorption coefficient (BAC; shoot-to-soil concentration ratio) and translocation factor (TF; shoot-to-root concentration ratio) were calculated for each species in contaminated $v$ s. reference uncontaminated soils. In calculating the above indexes, the soil DTPA extractability at the beginning of the trial was considered as the soil metal concentration, and tap-root and leaf metal concentrations as root and shoot metal concentrations, respectively.

\subsection{Plant Sampling in Critical Sites}

The same plant species used for the pot trial, growing spontaneously in potentially contaminated environments, were analysed during spring 2014, shoots and roots being collected separately, together with their rhizosphere soil $(n=3)$ from three sites in the province of Padova (NE Italy). Among the species studied, T. officinalis was collected in the carry-over soil covering a now completed urban waste landfill, from dragged ditch sediments and roadsides subjected to heavy traffic; $R$. acetosa was found in roadsides only.

\subsection{Statistical Analysis}

Statistical analysis was carried out by Statgraphics Centurion XV software (Manugistic., Rockville, MD, USA). ANOVA and the Newman-Keuls test $(p \leqslant 0.05)$ were used to evaluate differences among means for growth parameters and metal rates.

As stems were not present in some species/replicates of the pot trial, statistical analysis was not performed on this plant compartment.

\section{Results}

\subsection{Soil Contamination}

As a result of artificial metal supply, the level of target soil contamination was fully reached. Compared with the Italian Guideline Values (IGV, Italian Legislative Decree 152/2006) for "Green public, private and residential areas", pseudo-total Zn exceeded the IGV by $6 \times$ and Cu by $4 \times$, respectively, whereas $\mathrm{Co}, \mathrm{Cd}$ and $\mathrm{Pb}$ rates were almost double the maximum admitted level (Table 1 ). In the reference uncontaminated soil, as expected, all metals were largely below the IGV.

At the beginning of the experiment, metal DTPA extractability was also very high in contaminated soil, both as absolute value and fraction of total content, especially for $\mathrm{Cd}(83 \%), \mathrm{Cu}(45 \%)$ and $\mathrm{Zn}(41 \%)$; it was lower for $\mathrm{Pb}(\sim 25 \%)$ and $\mathrm{Co}(13 \%)$ (Table 1). Compared with the reference, contaminated soil had metal bioavailability $14 \times$ greater for $\mathrm{Pb}, 34 \times$ for $\mathrm{Cd}, 51 \times$ for $\mathrm{Cu}, 96 \times$ for $\mathrm{Co}$ and maximum for $\mathrm{Zn}$ $(239 \times)$. For the above five elements, metal bioavailability was positively correlated with total amounts in contaminated soil $\left(R^{2}=0.98\right)$, unlike the reference soil $\left(R^{2}=0.11\right)$. During pot cultivation, metal bioavailability (uncultivated) showed stable dynamics in the reference soil, but generally decreased over time in contaminated soil, except for $\mathrm{Pb}$, which initially increased moderately and then showed a decreasing trend (Figure 1). 
$\mathrm{Cd}$

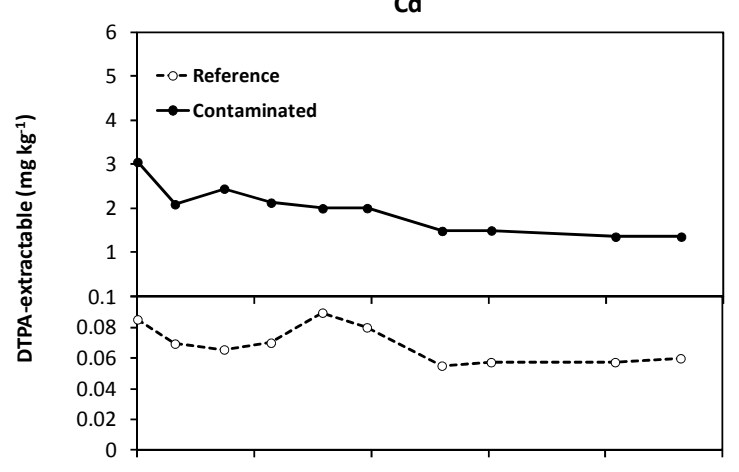

$\mathrm{Cu}$

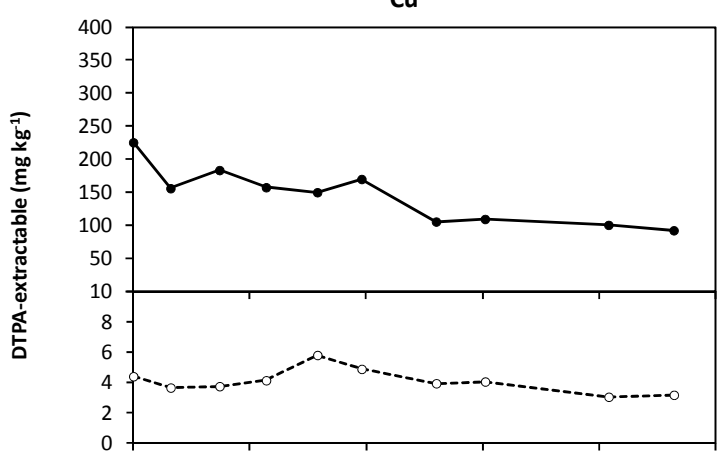

$\mathrm{Pb}$

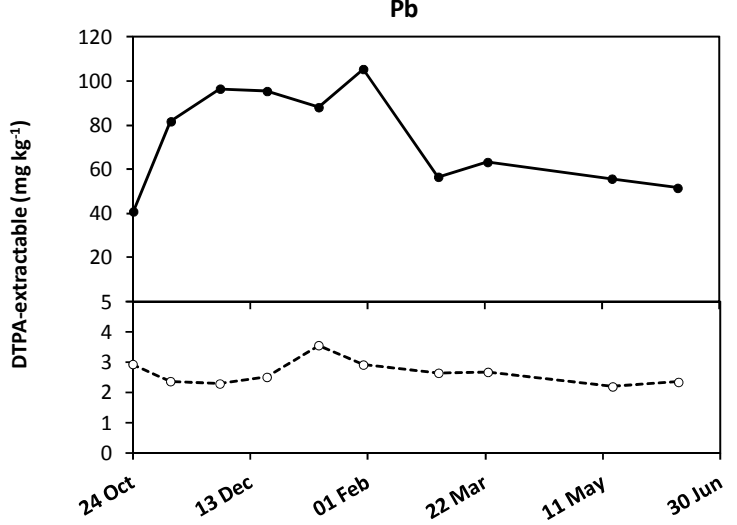

Co

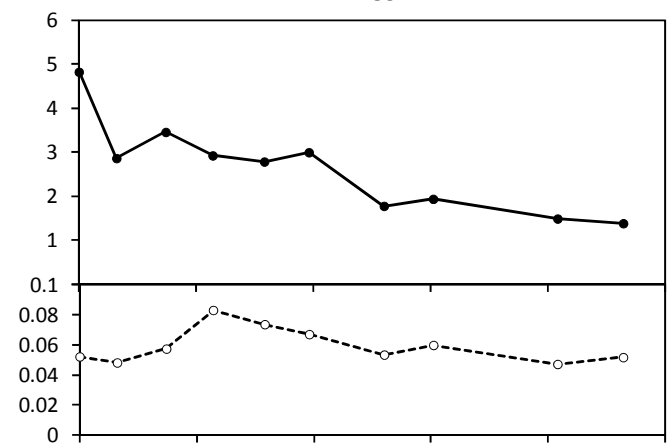

$\mathrm{Zn}$

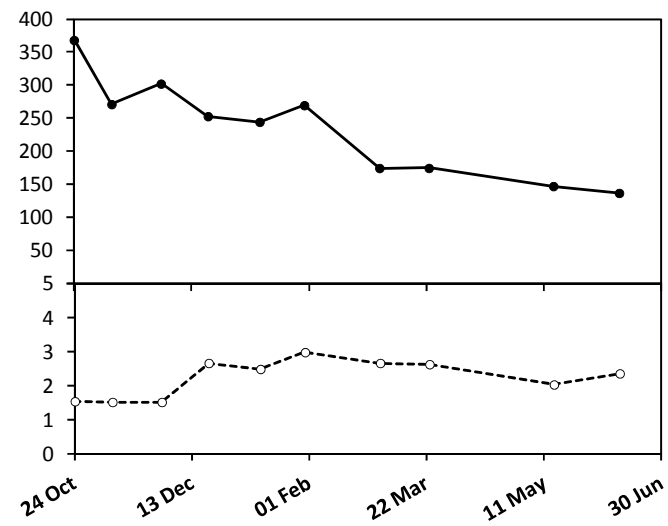

Figure 1. Dynamics of DTPA extractable metals ( $\left.\mathrm{mg} \cdot \mathrm{kg}^{-1} \mathrm{DW}, n=2\right)$ in contaminated and reference soils (both uncultivated). Note different scales among treatments and metals.

\subsection{Plant Growth and Metal Uptake}

Despite marked contamination, all species showed complete seed germination. Visual inspection also showed that plants apparently had good tolerance to contamination in terms of growth and greenness during the growing cycle, an observation supported by the SPAD chlorophyll contents, which were generally similar between treatments (data not shown). However, a slight delay in phenological phases was recorded with respect to controls, together with a general tendency towards lower biomass production (shoot + roots), except for R. acetosa and S. oleraceus, which grew almost normally (Figure 2a). Significant growth impairment was detected in T. porrifolius ( $-32 \%$ in whole plant), C. intybus ( $-45 \%$ ) and T. officinale ( $-75 \%)$, particularly at below-ground level (tap-root). In the contaminated environment, Sonchus and Taraxacum also showed a great reduction in fibrous root length, $-59 \%$ and $-73 \%$, respectively, whereas the other species only showed small variations (Figure $2 b$ ). As regards root distribution, Taraxacum, Cichorium and Rumex showed reduced root colonisation (\% of total length) in the deeper 10-20-cm soil layer (Figure 2c). 

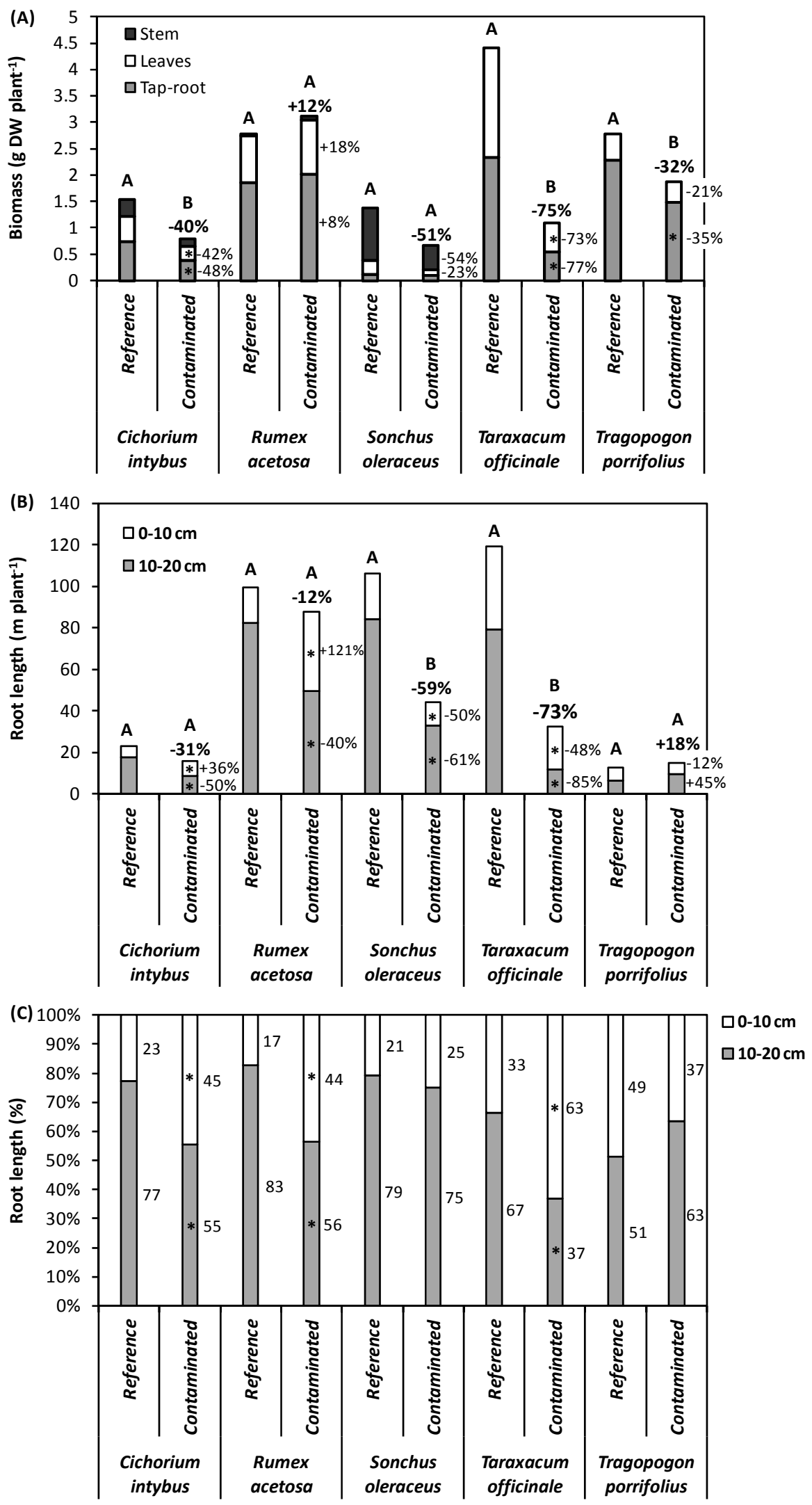

Figure 2. Biomass (A), root length (B) and distribution (C) in species grown in contaminated vs. reference soil $(n=3)$ in pot trial. Capital letters: differences among soils within same species for plant biomass and root length (\% variation with respect to reference soil). *: statistically significant differences between soils within same species and plant compartment or soil layer. 
The high values of total and bioavailable metals in contaminated soil were reflected in generalised increases in metal concentrations in plant tissues, particularly at root level (Figure 3). In contaminated soil, $\mathrm{Zn}$ and $\mathrm{Cu}$ reached the highest accumulations, with averages of 410 and $24 \mathrm{mg} \cdot \mathrm{kg}^{-1}$. DW above-ground, and 205 and $86 \mathrm{mg} \cdot \mathrm{kg}^{-1}$. DW below-ground, respectively. At leaf level, T. officinale had the highest $\mathrm{Zn}$ (shoot: $\sim 600 \mathrm{mg} \cdot \mathrm{kg}^{-1}$ ) and $C$. intybus the highest $\mathrm{Cu}\left(\sim 40 \mathrm{mg} \cdot \mathrm{kg}^{-1}\right), \mathrm{Cd}\left(\sim 16 \mathrm{mg} \cdot \mathrm{kg}^{-1}\right)$, $\mathrm{Co}\left(\sim 3 \mathrm{mg} \cdot \mathrm{kg}^{-1}\right)$ and $\mathrm{Pb}\left(\sim 4 \mathrm{mg} \cdot \mathrm{kg}^{-1}\right)$, i.e., generally moderate $\mathrm{Co}$ and $\mathrm{Pb}$. At root level, $\mathrm{T}$. officinale again had the highest $\mathrm{Zn}\left(\sim 400 \mathrm{mg} \cdot \mathrm{kg}^{-1}\right)$ together with $\mathrm{Cd}\left(\sim 9 \mathrm{mg} \cdot \mathrm{kg}^{-1}\right)$; Rumex acetosa had the highest $\mathrm{Cu}, \mathrm{Pb}$ and $\mathrm{Co}$, values being 130, 25 and $\sim 6 \mathrm{mg} \cdot \mathrm{kg}^{-1}$, respectively. As expected, higher root metal rates were found in contaminated vs. control treatments, regardless of metal and species choice, but this did not apply to the aerial biomass, as similar leaf values between treatments were measured for $\mathrm{Cu}$ and occasionally for $\mathrm{Pb}$ (C. intybus, R. acetosa, S. oleracerus) and $\mathrm{Co}$ (R. acetosa, S. oleracerus).

All tested species showed a high natural ability to take up and accumulate metals in both root and shoot compartments, as evidenced by the higher BCF and BAC recorded in the reference $v$ s. contaminated soil (Figure 4). In clean soil, both coefficients were largely $>1$, except for $\mathrm{Pb}$, whereas under contamination, BCF values were $>1$ for $\mathrm{Cd}$ (all species) and occasionally for $\mathrm{Co}$ (R. acetosa) and $\mathrm{Zn}$ (T. officinale). BAC values $>1$ were found for $\mathrm{Cd}$ and sometimes for $\mathrm{Zn}$ (T. officinale). The species rankings for $\mathrm{BCF}$ and $\mathrm{BAC}$ followed the root and leaf metal concentrations, respectively. This implied that high BCFs were generally found in Rumex and Taraxacum, and high BACs in Cichorium and Taraxacum.

The metal translocation factor (TF) from roots to harvestable biomass was typically lower in contaminated vs. clean soils for all species, due to significant root retention and moderate reduction of shoot biomass caused by contamination. According to the BAC ranking, TF confirmed that efficient metal translocation generally occurred in Rumex in the reference soil and to Cichorium in the contaminated soil. $\mathrm{Cd}$ and $\mathrm{Zn}$ were generally well translocated, whereas $\mathrm{Co}$ and $\mathrm{Cu}$ were mostly retained at root level. In both treatments, no significant correlation between total metal contamination and respective concentrations in plant organs could be found.

In view of the highest biomass yield under contamination, individual plants of $R$. acetosa also reached the highest metal accumulation in both above- and below-ground plant compartments, with an overall $\mathrm{Cd}+\mathrm{Co}+\mathrm{Cu}+\mathrm{Pb}+\mathrm{Zn}$ stock of $\sim 1.1 \mathrm{mg}$ per plant, followed by $\mathrm{T}$. officinale with half the $R$. acetosa value (Figure 5). At a suitable density of $15-20$ plants. $\mathrm{m}^{-2}$ for $R$. acetosa, an uptake of $\sim 230 \mathrm{~g} \cdot \mathrm{ha}^{-1}$ of various metals was estimated, $35 \%$ of which was removable by forage harvest. Despite the less-efficient uptake per individual plant, similar removals were estimated for T. porrifolius due to its potentially higher plant density (40-60 plants. $\left.\mathrm{m}^{-2}\right)$, with a higher fraction allocated in the harvestable above-ground biomass ( 40\%). Phytoextraction was feasible for $\mathrm{Zn}$ and partially for $\mathrm{Cu}$, and phytostabilisation for $\mathrm{Zn}, \mathrm{Cu}$ and $\mathrm{Pb}$.

Of the toxic metals, EC $1881 / 2006$ establishes $0.2 \mathrm{mg} \cdot \mathrm{kg}^{-1} \cdot \mathrm{FW}$ for $\mathrm{Cd}$ and $0.3 \mathrm{mg} \cdot \mathrm{kg}^{-1} \cdot \mathrm{FW}$ for $\mathrm{Pb}$ as maximum admitted levels in leaf vegetables for human consumption. Unfortunately, in all tested species, leaf $\mathrm{Cd}$ and $\mathrm{Pb}$ exceeded the above thresholds when cultivated in contaminated soil, especially in T. porrifolius and C. intybus, although potential concern may also arise in the clean soil, since the $\mathrm{Pb}$ level in R. acetosa was more than double that of the admitted threshold (Table 2). Compared with the maximum Cd level set for dry forage for animal feed $\left(1 \mathrm{mg} \cdot \mathrm{kg}^{-1}, 12 \%\right.$ humidity; EC 574/2011), all species exceeded the threshold in the polluted soil, but none in the reference soil. 


\begin{tabular}{|c|c|c|c|c|c|c|c|c|c|c|c|c|c|c|c|c|c|c|c|c|c|c|c|c|c|c|}
\hline \multirow{3}{*}{$\begin{array}{c}\text { Compartment } \\
\text { Tap-root }\end{array}$} & \multirow{3}{*}{$\begin{array}{c}\text { Species } \\
\text { Cichorium } \\
\text { intybus }\end{array}$} & \multicolumn{5}{|c|}{$\mathrm{Cd}$} & \multicolumn{5}{|c|}{ Co } & \multicolumn{5}{|c|}{$\mathrm{Cu}$} & \multicolumn{5}{|c|}{$\mathrm{Pb}$} & \multicolumn{5}{|c|}{$\mathrm{Zn}$} \\
\hline & & \multicolumn{2}{|c|}{ Reference } & \multicolumn{3}{|c|}{ Contaminated } & \multicolumn{2}{|c|}{ Reference } & \multicolumn{3}{|c|}{ Contaminated } & \multicolumn{2}{|c|}{ Reference } & \multicolumn{3}{|c|}{ Contaminated } & \multicolumn{2}{|c|}{ Reference } & \multicolumn{3}{|c|}{ Contaminated } & \multicolumn{2}{|c|}{ Reference } & \multicolumn{3}{|c|}{ Contaminated } \\
\hline & & 0.34 & $\mathrm{BC}$ & 3.52 & B & $* * *$ & 0.46 & B & 2.74 & BC & $* * *$ & 11.5 & B & 55.5 & B & $* * *$ & 1.14 & B & 11.1 & C & $* * *$ & 21.4 & $\mathrm{AB}$ & 182 & BC & $* * *$ \\
\hline & $\begin{array}{l}\text { Rumex } \\
\text { acetosa }\end{array}$ & 0.16 & $\mathrm{D}$ & 1.48 & C & $* * *$ & 0.9 & A & 5.67 & A & $* *$ & 10.6 & B & 130 & A & $* * *$ & 2.66 & A & 25.4 & A & $* *$ & 30.4 & A & 198 & B & $* *$ \\
\hline & $\begin{array}{l}\text { Sonchus } \\
\text { oleraceus }\end{array}$ & 0.78 & A & 4.14 & B & $* * *$ & 0.48 & $\mathrm{AB}$ & 3.51 & BC & n.s. & 63.4 & A & 102 & A & n.s. & 1.66 & $\mathrm{AB}$ & 12.0 & $\mathrm{BC}$ & n.s. & 28.1 & $\mathrm{AB}$ & 149 & BC & $* *$ \\
\hline & $\begin{array}{l}\text { Taraxacum } \\
\text { officinale }\end{array}$ & 0.4 & B & 8.69 & A & $* * *$ & 0.33 & B & 3.94 & $\mathrm{AB}$ & * & 18.8 & B & 94.3 & A & $*$ & 0.88 & B & 21.6 & $\mathrm{AB}$ & * & 21.3 & BC & 396 & A & $* *$ \\
\hline & $\begin{array}{l}\text { Tragopogon } \\
\text { porrifolius }\end{array}$ & 0.27 & $\mathrm{CD}$ & 3.31 & B & $* * *$ & 0.39 & B & 1.76 & C & $* * *$ & 12.7 & B & 46.8 & B & $* * *$ & 0.94 & B & 7.85 & C & $* *$ & 19.4 & $\mathrm{C}$ & 101 & C & $* * *$ \\
\hline & Mean & 0.39 & & 4.23 & & $* * *$ & 052 & & 4.52 & & $* * *$ & 23.4 & & 85.7 & & $* * * *$ & 1.42 & & 15.6 & & $* * * *$ & 24.1 & & 205 & & $* * *$ \\
\hline \multirow[t]{6}{*}{ Leaves } & $\begin{array}{l}\text { Cichorium } \\
\text { intybus }\end{array}$ & 0.85 & A & 15.8 & A & $* * *$ & 0.29 & A & 2.90 & A & $*$ & 16.0 & A & 37.7 & A & n.s. & 0.82 & B & 4.05 & A & n.s. & 41.2 & A & 497 & A & $* * *$ \\
\hline & $\begin{array}{l}\text { Rumex } \\
\text { acetosa }\end{array}$ & 0.31 & B & 1.62 & D & $* * *$ & 0.99 & A & 1.28 & B & n.s. & 13.9 & A & 17.4 & B & n.s. & 4.25 & A & 3.41 & A & n.s. & 51.7 & A & 363 & B & $* * *$ \\
\hline & $\begin{array}{l}\text { Sonchus } \\
\text { oleraceus }\end{array}$ & 0.82 & A & 9.17 & C & $* * *$ & 0.11 & A & 0.47 & B & n.s. & 16.1 & A & 22.4 & B & n.s. & 0.39 & B & 2.34 & A & n.s. & 29.5 & A & 250 & B & $* *$ \\
\hline & $\begin{array}{c}\text { Taraxacum } \\
\text { officinale }\end{array}$ & 0.56 & $\mathrm{AB}$ & 12.5 & B & $* * *$ & 0.14 & A & 1.04 & B & $* *$ & 20.2 & A & 20.8 & B & n.s. & 0.44 & B & 1.56 & A & $* *$ & 31.8 & A & 597 & A & $* * *$ \\
\hline & $\begin{array}{l}\text { Tragopogon } \\
\text { porrifolius }\end{array}$ & 0.71 & $\mathrm{AB}$ & 12.8 & B & $* * *$ & 0.14 & A & 1.45 & B & $* *$ & 13.2 & A & 21.5 & B & n.s. & 0.64 & B & 1.86 & A & * & 32.4 & A & 341 & B & $* *$ \\
\hline & Mean & 0.65 & & 10.4 & & $* * *$ & 0.39 & & 1.43 & & ** & 15.9 & & 24.0 & & ** & 1.31 & & 2.64 & & n.s. & 37.3 & & 409 & & $* * *$ \\
\hline \multirow[t]{6}{*}{ Stem } & $\begin{array}{c}\text { Cichorium } \\
\text { intybus }\end{array}$ & 3.87 & & 2.62 & & & 1.55 & & 1.14 & & & 15.4 & & 13.1 & & & 0.35 & & 0.51 & & & 129 & & 97 & & \\
\hline & $\begin{array}{l}\text { Rumex } \\
\text { acetosa }\end{array}$ & - & & 1.55 & & & - & & 0.38 & & & 3.81 & & 9.78 & & & - & & 0.51 & & & 15.2 & & 220 & & \\
\hline & $\begin{array}{l}\text { Sonchus } \\
\text { oleraceus }\end{array}$ & 0.42 & & 4.17 & & & - & & 0.17 & & & 13.6 & & 9.46 & & & - & & 0.39 & & & 18.9 & & 77.3 & & \\
\hline & $\begin{array}{c}\text { Taraxacum } \\
\text { officinale }\end{array}$ & - & & - & & & - & & - & & & - & & - & & & - & & - & & & - & & - & & \\
\hline & $\begin{array}{l}\text { Tragopogon } \\
\text { porrifolius }\end{array}$ & - & & - & & & - & & - & & & - & & - & & & - & & - & & & - & & - & & \\
\hline & Mean & 1.28 & & 2.93 & & & 1.55 & & 0.62 & & & 12.0 & & 10.9 & & & 0.35 & & 0.45 & & & 40.1 & & 120 & & \\
\hline
\end{tabular}

Capital letters: differences among species within same soil and compartment (Newman-Keuls test, $p \leq 0.05$ ). n.s., ${ }^{*}, * *$, ***: significance for reference $v s$. contaminated soil comparison within same metal, compartment and species (not significant, $p \leq 0.05, p \leq 0.01, p \leq 0.001$, respectively). Highlighted values: maxima in reference (pale grey) and contaminated (dark grey) soils.

Figure 3. Metal concentrations ( $\left.\mathrm{mg} \cdot \mathrm{kg}^{-1} \mathrm{DW}, n=3\right)$ in plant compartments as function of soil contamination in pot trial. 


\begin{tabular}{|c|c|c|c|c|c|c|c|c|c|c|c|c|c|c|c|c|c|c|c|c|c|c|c|}
\hline & $\mathrm{Cd}$ & & & & Co & & & & & $\mathrm{Cu}$ & & & & & $\mathrm{Pb}$ & & & & $\mathrm{Zn}$ & & & & \\
\hline & Reference & & Contaminated & & Reference & & Contaminated & & & eference & & Contaminated & & & eference & & Contaminated & & Referenc & e $\mathrm{C}$ & Contaminatec & & \\
\hline BCF Cichorium intybus & 4.02 & $\mathrm{~B}$ & 1.15 & $\mathrm{~B}^{* * *}$ & 9.70 & $\mathrm{~A}$ & 0.57 & $\mathrm{~B}$ & ** & 2.60 & $\mathrm{~B}$ & 0.25 & $\mathrm{~B}^{*}$ & $* * *$ & 0.39 & $\mathrm{~B}$ & 0.27 & BCn.s. & 14.0 & $\mathrm{~A}$ & 0.49 & B & $* * *$ \\
\hline Rumex acetosa & 1.93 & C & 0.49 & $C^{* *}$ & 17.3 & A & 1.18 & A & * & 2.42 & B & 0.58 & $A=$ & $* *$ & 0.91 & A & 0.62 & A n.s. & 19.8 & A & 0.54 & B & $* *$ \\
\hline Sonchus oleraceus & 9.16 & A & 1.36 & $\mathrm{~B}^{* * *}$ & 9.21 & A & 0.73 & $\mathrm{AB}^{*}$ & & 14.4 & A & 0.45 & A & * & 0.57 & $\mathrm{AB}$ & 0.29 & $\mathrm{BC} * * *$ & 18.3 & A & 0.41 & B & $* * *$ \\
\hline $\begin{array}{c}\text { Taraxacum } \\
\text { officinale }\end{array}$ & 4.72 & B & 2.85 & An.s. & 6.23 & A & 0.82 & $\mathrm{AB}$ & * & 4.27 & B & 0.42 & A $n$ & h.s. & 0.30 & B & 0.53 & ABn.s. & 13.9 & A & 1.07 & A & $* * *$ \\
\hline $\begin{array}{l}\text { Tragopogon } \\
\text { porrifolius }\end{array}$ & 3.16 & $\mathrm{BC}$ & 1.09 & $\mathrm{~B}^{* *}$ & 7.52 & A & 0.37 & $B=$ & ** & 2.88 & B & 0.21 & $B$ * & $* * *$ & 0.32 & B & 0.19 & C n.s. & 12.6 & A & 0.27 & B & $* * *$ \\
\hline Mean & 4.60 & & 1.39 & $* * *$ & 10.14 & & 0.73 & & $* * *$ & 5.32 & & 0.38 & & ** & 0.49 & & 0.38 & n.s. & 15.7 & & 0.56 & & $* * *$ \\
\hline BACCichorium intybus & 9.97 & A & 5.19 & $A^{* * *}$ & 5.50 & A & 0.60 & $\mathrm{~A}$ & $* *$ & 3.64 & A & 0.17 & $A$ & $* *$ & 0.28 & A & 0.10 & $\mathrm{~A} *$ & 26.8 & A & 1.35 & $\mathrm{~A}$ & $* * *$ \\
\hline Rumex acetosa & 3.67 & A & 0.53 & $D^{*}$ & 19.0 & A & 0.27 & $\mathrm{~B} n$ & c.s. & 3.17 & A & 0.08 & A $n$ & a.s. & 1.45 & A & 0.08 & A n.s. & 33.6 & A & 0.99 & B & $*$ \\
\hline Sonchus oleraceus & 9.67 & A & 3.01 & Cn.s. & 2.09 & A & 0.10 & $B$ & ** & 3.65 & A & 0.10 & $A$ & ** & 0.13 & A & 0.06 & A n.s. & 19.2 & A & 0.68 & B & * \\
\hline $\begin{array}{c}\text { Taraxacum } \\
\text { officinale }\end{array}$ & 6.57 & A & 4.10 & B n.s. & 2.60 & A & 0.22 & $B *$ & $* * *$ & 4.59 & A & 0.09 & $A *$ & $* * *$ & 0.15 & A & 0.04 & A *** & 20.7 & A & 1.62 & A & $* *$ \\
\hline $\begin{array}{l}\text { Tragopogon } \\
\text { porrifolius }\end{array}$ & 8.36 & A & 4.19 & $B * *$ & 2.73 & A & 0.30 & $B *$ & $* * *$ & 3.00 & A & 0.10 & $A$ * & $* * *$ & 0.22 & A & 0.05 & A & 21.1 & A & 0.92 & B & $* *$ \\
\hline Mean & 7.65 & & 3.40 & $* * *$ & 7.43 & & 0.30 & & ** & 3.61 & & 0.11 & & **** & 0.45 & & 0.06 & n.s. & 24.3 & & 1.11 & & $* * *$ \\
\hline TF Cichorium intybus & 2.48 & A & 4.49 & $\mathrm{~A}^{* * *}$ & 0.64 & A & 1.04 & A n & h.s. & 1.39 & A & 0.67 & A & $*$ & 0.75 & A & 0.35 & A n.s. & 1.92 & A & 2.74 & $\mathrm{AB}$ & $3 *$ \\
\hline Rumex acetosa & 2.06 & A & 1.11 & Dn.s. & 1.38 & A & 0.24 & B n & h.s. & 1.53 & A & 0.14 & B $n$ & h.s. & 1.96 & A & 0.15 & A n.s. & 1.79 & A & 1.92 & $\mathrm{~B}$ & n.s. \\
\hline Sonchus oleraceus & 1.04 & A & 2.22 & $C *$ & 0.22 & A & 0.15 & $\mathrm{~B} n$ & t.s. & 0.28 & A & 0.23 & B $n$ & n.s. & 0.21 & A & 0.24 & A n.s. & 1.02 & A & 1.77 & $\mathrm{~B}_{1}$ & n.s. \\
\hline $\begin{array}{c}\text { Taraxacum } \\
\text { officinale }\end{array}$ & 1.40 & A & 1.45 & Dn.s. & 0.32 & A & 0.29 & B n & h.s. & 1.45 & A & 0.23 & B n & h.s. & 0.58 & A & 0.09 & A * & 1.49 & A & 1.54 & B 1 & n.s. \\
\hline $\begin{array}{l}\text { Tragopogon } \\
\text { porrifolius }\end{array}$ & 2.70 & A & 3.87 & $B *$ & 0.37 & A & 0.83 & A & * & 1.04 & A & 0.47 & $\mathrm{AB}$ & * & 0.78 & A & 0.26 & A n.s. & 1.74 & $\mathrm{~A}$ & 3.36 & A & * \\
\hline Mean & 1.94 & & 2.63 & n.s. & 0.63 & & 0.51 & & i.s. & 1.14 & & 0.35 & & $* * *$ & 0.96 & & 0.22 & * & 1.59 & & 2.26 & & * \\
\hline
\end{tabular}

BCF: taproot-to-soil metal concentration ratio. BAC: leaf-to-soil metal concentration ratio. TF: leaf-to-taproot concentration ratio. DTPA extractability used as soil metal concentration. Capital letters: statistically significant differences among species within same metal and soil (Newman-Keuls test, $p \leq 0.05$ ). n.s., $* * *, * * *$ differences among treatments within same metal and species (not significant, $p \leq 0.05, p \leq 0.01, p \leq 0.001$, respectively). Highlighted values: maxima in reference (pale grey) and contaminated (dark grey) soils.

Figure 4. Metal bioconcentration factor (BCF), biological absorption coefficient (BAC) and translocation factor (TF) in species grown in contaminated vs. reference soil $(n=3)$ in pot trial. 

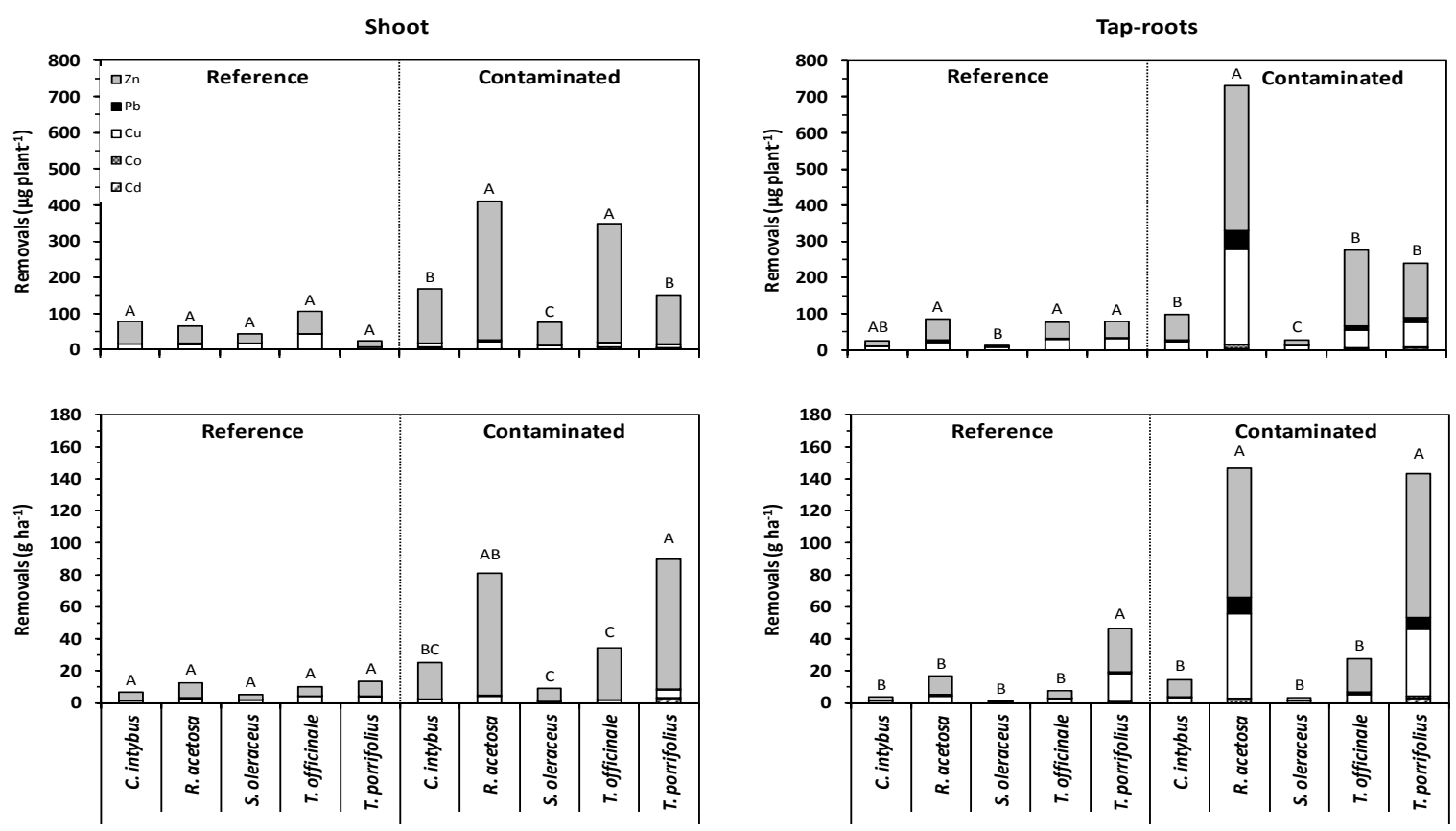

Figure 5. Metal removals by shoots (leaves + stems) and tap-roots $(n=3)$ per plant (top) and estimate per hectare (bottom) in pot trial. Plant density per $\mathrm{m}^{2}$ : C. intybus: 15; R. acetosa: 20; S. oleraceus: 12; T. officinale: 10; T. porrifolius: 60 . Letters: differences between species for overall removals within same soil (Newman-Keuls test, $p \leqslant 0.05$ ).

Table 2. Leaf $\mathrm{Cd}$ and $\mathrm{Pb}$ concentrations of species grown in pot trial and in potentially contaminated open environments (mg. $\mathrm{kg}^{-1} \mathrm{FW}, n=3$ ) compared with limits for food uses (Cd: $0.2 ; \mathrm{Pb}: 0.3 \mathrm{mg} \cdot \mathrm{kg}^{-1} \cdot \mathrm{FW}$ ).

\begin{tabular}{ccccccc}
\hline & Soil & $\begin{array}{c}\text { Cichorium } \\
\text { intybus }\end{array}$ & $\begin{array}{c}\text { Rumex } \\
\text { acetosa }\end{array}$ & $\begin{array}{c}\text { Sonchus } \\
\text { oleraceus }\end{array}$ & $\begin{array}{c}\text { Taraxacum } \\
\text { officinale }\end{array}$ & $\begin{array}{c}\text { Tragopogon } \\
\text { porrifolius }\end{array}$ \\
\hline $\mathrm{Cd}$ & Reference (pot) & 0.19 & 0.05 & 0.18 & 0.11 & 0.18 \\
& Contaminated (pot) & 2.90 & 0.26 & 1.95 & 2.08 & 3.02 \\
& Roadside & - & 0.03 & - & 0.05 & - \\
& Landfill & - & - & - & 0.04 & - \\
\hline $\mathrm{Pb}$ & Field ditch & - & - & - & 0.04 & - \\
& Reference (pot) & 0.18 & 0.68 & 0.09 & 0.09 & 0.16 \\
& Contaminated (pot) & 0.74 & 0.55 & 0.50 & 0.26 & 0.44 \\
& Roadside & - & 0.34 & - & 0.21 & - \\
& Landfill & - & - & - & 0.21 & - \\
& Field ditch & - & - & - & 0.21 & - \\
\hline
\end{tabular}

Note values are on fresh weight (FW). Highlighted values: exceeding European limits for food uses (EC 1881/2006). Empty cells: no species found in critical open environments.

\subsection{Metal Leaching}

Metal leaching was clearly affected by the intensity of water percolation, which was accentuated in uncultivated soil and in contaminated pots. Only in Rumex and Cichorium were percolation volumes similar between treatments, probably due to comparable shoot growth and transpiration. This translated into generally higher metal leaching in polluted soil, particularly when not cultivated, but also with Taraxacum and Sonchus. Low metal losses were found in C. intybus, R. acetosa and T. porrifolius (Figure 6). $\mathrm{Zn}$ and $\mathrm{Cu}$ represented almost all the leachate, on average $60 \%$ and $~ 35 \%$, respectively, fractions which were very stable across species and treatments. Instead, Cd, Co and $\mathrm{Pb}$ percolation was negligible. In clean soil, increased metal leaching was usually observed in cultivated soil, regardless of species choice. As regards contaminated soil data only, overall leaching of 
$\mathrm{Co}+\mathrm{Cd}+\mathrm{Cu}+\mathrm{Pb}+\mathrm{Zn}$ was negatively correlated with plant biomass $\left(\mathrm{R}^{2}=0.15\right)$, particularly for $\mathrm{Cd}$; values for $\mathrm{Co}$ and $\mathrm{Cu}$ also fell as fibrous root length increased $\left(\mathrm{R}^{2}=0.24\right.$ and 0.47 , respectively).
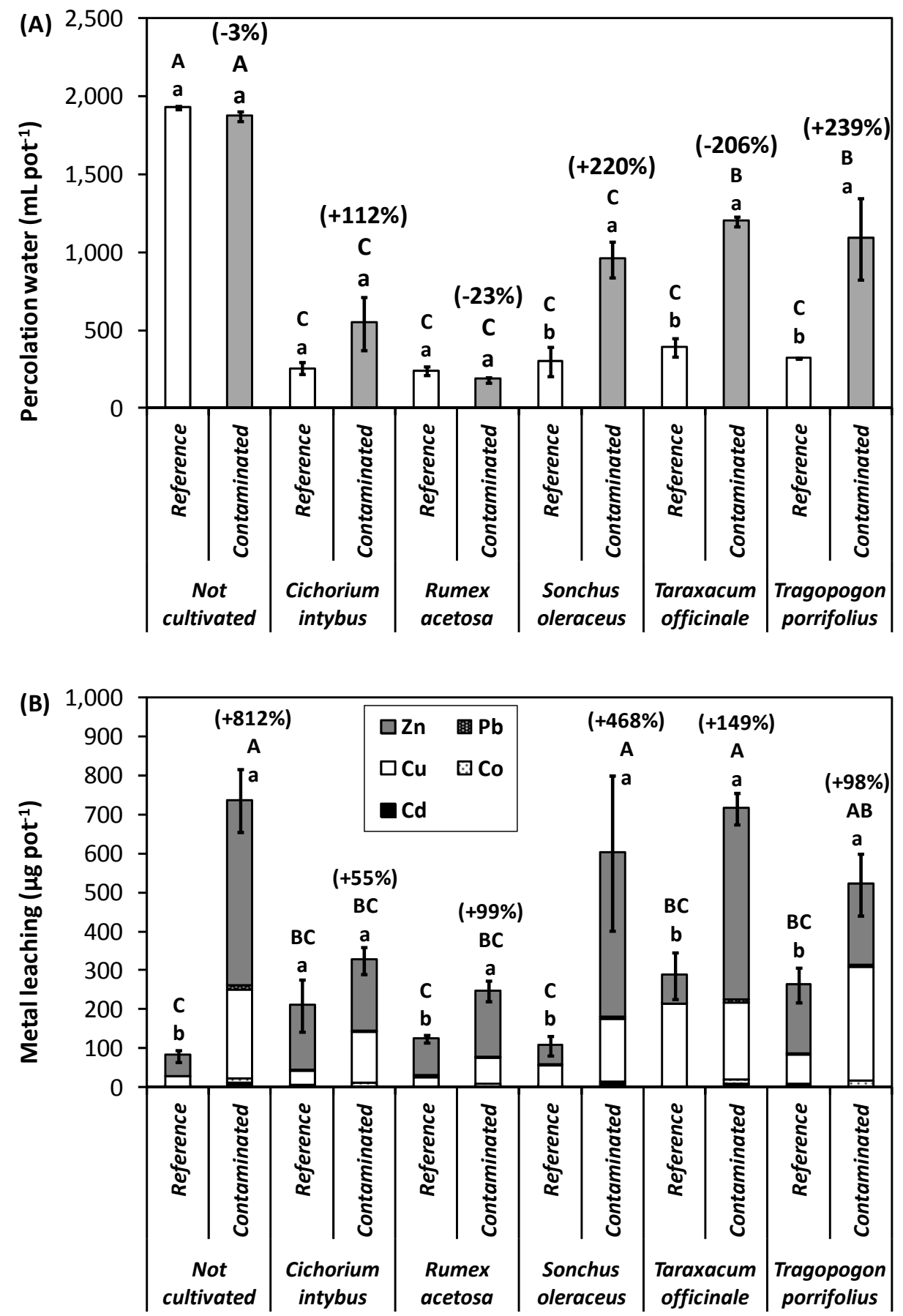

Figure 6. Water percolation volumes $( \pm$ S.E., $n=3)(\mathbf{A})$ and overall metal leaching $( \pm$ S.E., $n=3)(\mathbf{B})$ in pot trial. In brackets: percentage of variation with respect to reference soil. Capital letters: significance for multiple comparisons. Small letters: differences between soils within same species (Newman-Keuls test, $p \leqslant 0.05)$.

\subsection{Vegetation Grown at Potentially Polluted Sites}

In critical open environments, soil rarely turned out to be contaminated, the only exception being highly trafficked roadsides, where $\mathrm{Zn}$ exceeded $\sim 2 \times \mathrm{IGV}$ and $\mathrm{Pb} 1.4 \times$ (Table 3). Total soil metal 
concentrations were positively correlated with DTPA extractability $\left(p \leqslant 0.001, \mathrm{R}^{2}=0.56\right.$ for $\mathrm{Cd}, 0.93$ for $\mathrm{Zn}$ ), and bioavailability was a key soil trait for $\mathrm{Pb}$ accumulation in both leaves and roots in roadsides $\left(R^{2}=0.42\right.$ and 0.81 for shoot and root, respectively). In both plant compartments, T. officinale efficiently accumulated $\mathrm{Zn}$ and $\mathrm{Cu}$ and Rumex acetosa $\mathrm{Pb}$, with values generally lower than those found in the contaminated soil of the pot trial, but almost double those of the uncontaminated pots. Cd was poorly taken up and did not exceed $0.33 \mathrm{mg} \cdot \mathrm{kg}^{-1}$. plant. DW (Table 3).

Table 3. Metal concentration (mg. $\left.\mathrm{kg}^{-1} \mathrm{DW}, n=3\right)$ in soil and plant compartments of species collected in critical open environments.

\begin{tabular}{cccccccccc}
\hline \multirow{2}{*}{ Metal } & \multirow{2}{*}{ Compartment } & \multicolumn{5}{c}{ Rumex acetosa } & \multicolumn{5}{c}{ Taraxacum officinale } \\
\cline { 3 - 9 } & & \multicolumn{2}{c}{ Roadside } & Landfill & \multicolumn{2}{c}{ Field Ditch } & Roadside \\
\hline \multirow{2}{*}{$\mathrm{Cd}$} & Soil & $0.60(27 \%)$ & $\mathrm{a}$ & $0.16(45 \%)$ & $\mathrm{c}$ & $0.17(34 \%)$ & $\mathrm{c}$ & $0.33(25 \%)$ & $\mathrm{b}$ \\
& Tap-root & 0.27 & $\mathrm{a}$ & 0.32 & $\mathrm{a}$ & 0.28 & $\mathrm{a}$ & 0.33 & $\mathrm{a}$ \\
& Leaves & 0.17 & $\mathrm{a}$ & 0.22 & $\mathrm{a}$ & 0.20 & $\mathrm{a}$ & 0.25 & $\mathrm{a}$ \\
\hline $\mathrm{Cu}$ & Soil & $97.8(21 \%)$ & $\mathrm{b}$ & $23.6(16 \%)$ & $\mathrm{b}$ & $41.9(11 \%)$ & $\mathrm{b}$ & $322(14 \%)$ & $\mathrm{a}$ \\
& Tap-root & 12.5 & $\mathrm{a}$ & 22.5 & $\mathrm{a}$ & 24.1 & $\mathrm{a}$ & 25.6 & $\mathrm{a}$ \\
& Leaves & 10.0 & $\mathrm{~b}$ & 10.0 & $\mathrm{~b}$ & 21.3 & $\mathrm{a}$ & 15.3 & $\mathrm{ab}$ \\
\hline $\mathrm{Pb}$ & Soil & $139(21 \%)$ & $\mathrm{a}$ & $18.3(16 \%)$ & $\mathrm{c}$ & $29.6(11 \%)$ & $\mathrm{bc}$ & $70.6(7 \%)$ & $\mathrm{b}$ \\
& Tap-root & 5.38 & $\mathrm{a}$ & 0.47 & $\mathrm{c}$ & 1.18 & $\mathrm{bc}$ & 1.78 & $\mathrm{~b}$ \\
& Leaves & 1.68 & $\mathrm{a}$ & 0.48 & $\mathrm{~b}$ & 1.03 & $\mathrm{ab}$ & 1.03 & $\mathrm{ab}$ \\
\hline $\mathrm{Zn}$ & Soil & $229(15 \%)$ & $\mathrm{b}$ & $81.0(3 \%)$ & $\mathrm{c}$ & $114(2 \%)$ & $\mathrm{c}$ & $326(14 \%)$ & $\mathrm{a}$ \\
& Tap-root & 63.1 & $\mathrm{~b}$ & 42.1 & $\mathrm{~b}$ & 174 & $\mathrm{a}$ & 59.6 & $\mathrm{~b}$ \\
& Leaves & 49.3 & $\mathrm{~b}$ & 43.4 & $\mathrm{~b}$ & 90.9 & $\mathrm{a}$ & 56.3 & $\mathrm{~b}$ \\
\hline
\end{tabular}

Letters: differences among species/sites within same metal and compartment (Newman-Keuls test, $p \leqslant 0.05)$. In brackets: \% of metal bioavailability in soil (DTPA extraction).

In these conditions, metal translocation from roots to shoot was seldom high, values ranging from 0.7 for Cd to 1.1 for $\mathrm{Zn}$. The quality of Taraxacum leaves for human consumption (EC 1881/2006) was not compromised at all, although $\mathrm{Pb}$ slightly exceeded the safety threshold in $R$. acetosa $(1.13 \times)$. No concern arose regarding the forage use of either species.

\section{Discussion}

\subsection{Plant Responses to Metal Contaminants and Perspectives for Phytoremediation}

Phytoremediation of metal-contaminated sites may consider two strategies, the use of hyperaccumulator species, which generally yield small biomasses rich in one or a few contaminants, and high-yielding species (including crops), with low or medium contaminant concentrations. As the research community is constantly searching for efficient new species for particular environments characterised by multiple metal contamination, in this study five polyannual tap-rooted alimurgic species with the potential to combine both phytoextraction and medium-term metal stabilisation within roots were examined. Apart from T. porrifolius, a biennial wild flower native to the Mediterranean region, the behaviour of which has not yet been studied, the literature provides interesting reports for the other species. The cosmopolitan T. officinale is recognised as an indicator of $\mathrm{Cd}, \mathrm{Pb}, \mathrm{Cu}$ and $\mathrm{Zn}$ [24-26], and C. intybus is already known for its interesting $\mathrm{Zn}$ and $\mathrm{Cu}$ above-ground accumulations, up to $\sim 150$ and $\sim 20 \mathrm{mg} \cdot \mathrm{kg}^{-1}$, respectively [18,27-29]. The possible high leaf $\mathrm{Cd}\left(\sim 50 \mathrm{mg} \cdot \mathrm{kg}^{-1}\right.$. DW) also suggests its use as a $\mathrm{Cd}$ indicator, and the extremely high $\mathrm{Pb}\left(>1.1 \mathrm{~g} \cdot \mathrm{kg}^{-1}\right.$. DW) allows it to be classified as a $\mathrm{Pb}$ hyperaccumulator [30]. S. oleraceus is a common weed in pastures, disturbed areas and contaminated roadsides, being tolerant to high soil $\mathrm{Pb}$ [31] and capable of accumulating above-ground up to $1.6 \mathrm{~g} \cdot \mathrm{Pb} \cdot \mathrm{kg}^{-1}$ and $2.5 \mathrm{~g} \cdot \mathrm{Zn} \cdot \mathrm{kg}^{-1}$ in degraded environments [17]. R. acetosa is a pseudo-metallophyte colonising contaminated sites [32-34], and, in mining areas, some accessions can achieve $\mathrm{Zn}$ removals comparable with those of hyperaccumulator species [16]. 
Here it was demonstrated that all these species have good tolerance to elevated total and bioavailable soil metal contamination, although in this study seeds came from agricultural soils rather than from metalliferous areas, where selection of more efficient accessions commonly occurs. Seed germination was not affected at all-a result also found in various Brassicaceae growing under high rates of toxic metals in hydroponics [35]. The maintenance of normal leaf chlorophyll contents, which is generally compromised under marked contamination due to $\mathrm{Mg}$ substitution by bivalent metals, was also an interesting result [36].

From these alimurgics, it is expected to reach significantly higher contaminant concentrations in biomasses than from herbaceous crops and woody species in severely contaminated wastes [37-39]. Appreciable accumulations of various metals were found in Rumex below-ground and in Cichorium above-ground, and $\mathrm{Zn}$ in both plant compartments of Taraxacum. This suggests that biochemical mechanisms of tolerance, such as chelation, compartmentalisation and antioxidation allow plants to accumulate several elements efficiently at the same time. Some of the tested species were pseudo-metallophytes, but hyperaccumulation levels like those reported by Bech et al. [17] for S. oleraceus in contaminated sites of the Peruvian Andes (Pb: $4.2-111 \mathrm{~g} \cdot \mathrm{kg}^{-1}$; $\mathrm{Zn}: 8.8-46.5 \mathrm{~g} \cdot \mathrm{kg}^{-1}$ ) were never recorded in this study. Leaf $\mathrm{Cd}$ and $\mathrm{Pb}$ in Cichorium ( 16 and $\sim 4 \mathrm{mg} \cdot \mathrm{kg}^{-1}$, respectively), although interesting, were far from those found by Del Río-Celestino et al. [30]. In this regard, it should be borne in mind that $400 \mathrm{mg} \cdot \mathrm{Zn} \cdot \mathrm{kg}^{-1} \mathrm{DW}$ and $30 \mathrm{mg} \cdot \mathrm{Cd} \cdot \mathrm{kg}^{-1} \mathrm{DW}$ leaf concentrations are considered the upper toxic levels in several plants [40].

In applying alimurgic species to the phytomanagement of degraded environments, it should be considered that feasible phytoextraction regards only a few essential metals, like $\mathrm{Zn}$ and $\mathrm{Cu}$, as it occurs in many crops, whereas the more noxious $\mathrm{Cd}$ and $\mathrm{Pb}$ are excluded or mainly retained at root level [35]. The quantities of metals immobilised in tap-roots are expected to be more than double those above-ground-an interesting result which can be exploited in phytostabilisation, particularly for Zn and $\mathrm{Cu}$, but also for $\mathrm{Pb}$. The natural ability of all the species studied here to take up heavy metals in the absence of real contamination (reference soil) indicates the probable physiological role of metals against diseases or abiotic stress (e.g., cold, drought) during their cycle, although species ranking could only really be obtained in the severe contamination conditions of this trial.

Despite appreciable plant metal rates, biomass productivity was identified as one main constraint in achieving efficient phytoremediation. The removals per hectare provided here were calculated from species-specific plant densities reported in the literature, but further studies are probably necessary to confirm these estimates. In the meantime, a dense mixed community of wild species would improve visually degraded sites and possibly increase animal biodiversity, yielding metal-rich biomasses for energy purposes and reducing wind erosion and metal percolation. This last aspect is often neglected, and the most important way of reducing metal leaching is limiting water percolation by establishing a highly transpiring vegetation cover. The essential role of roots in reducing metal leaching through uptake or soil immobilization has already been demonstrated [41,42]. Matching the mobilizing effect of roots in rhizospheric soil $[43,44]$, higher leaching with vegetation cover in uncontaminated pots is expected, compared with uncultivated controls. Root morphology (surface area, diameter, tip density) generally plays an important role in nutrient and metal accumulation, especially for the less mobile Cd [45], and better tolerance to contamination should be expected when root distribution is moved downwards, as found in Sonchus and Tragopogon.

\subsection{Food Safety}

Enrichment of plant materials with essential metals is receiving increasing attention, and various agronomic practices have been applied for improving basic foods in agricultural soil [13,14]. Exploiting metal-rich soils for this purpose is worthwhile if noxious elements are not present or are selectively excluded by plants. In the species studied here, opportunities for natural above-ground improvements involved $\mathrm{Zn}$ and occasionally $\mathrm{Co}$, but not $\mathrm{Cu}$, whereas problems are encountered with $\mathrm{Cd}$ and occasionally $\mathrm{Pb}$ (Taraxacum and Tragopogon), which are accumulated at the same time. In the absence of 
contamination by noxious metals, alimurgic species might provide functional foods or fortified food additive powders [46], or they may even be converted into amendants to alleviate soil micronutrient deficiencies, as suggested by [47] for poplar B-enriched leaves, although real applications are still lacking in this field. Instead, in critical conditions, particularly in the case of multiple contamination, the alimurgic species studied here represent a pathway to exposure, allowing toxic elements to enter the food chain, either through direct human consumption or animal feeding, since they commonly develop in pastures. As food, these species are traditionally gathered in meadows, field edges, along paths flanking watercourses, and roadsides, where hazardous levels of toxic metals are easily encountered. Among the examined sites, hazardous contamination was found in highly trafficked roadsides, where both Rumex and Taraxacum exhibited levels of leaf $\mathrm{Zn}$ and $\mathrm{Pb}$ higher than those found in the clean agricultural pot soil. Roadsides are especially affected by several types of emissions, such as dust from tyre and clutch disc wear, chemicals from winter road maintenance and combustion gases, and $\mathrm{Pb}$ and $\mathrm{Cd}$ are two of the main pollutants. Although positive relationships between total and bioavailable metals and plant uptake were seldom found, in roadsides or near mining areas leaf absorption cannot be excluded, and its intensity may depend on leaf roughness and wax abundance [48].

European legislation has not yet provided maximum levels of metals in medicinal plants, and the current reference is to EC $1881 / 2006$ thresholds for leaf vegetables, which establishes $0.2 \mathrm{mg} \cdot \mathrm{Cd} \cdot \mathrm{kg}^{-1}$ FW and $0.3 \mathrm{mg} \cdot \mathrm{Pb} \cdot \mathrm{kg}^{-1} \mathrm{FW}$, although the WHO [49] proposed respective thresholds of $10 \mathrm{for} \mathrm{Cd}$ and 0.3 for $\mathrm{Pb}$ on $\mathrm{DW}$. Leaves are generally more exposed to metal contamination than seeds, kernels or achenes, and the risks represented by $\mathrm{Cd}$ and $\mathrm{Pb}$ are real for almost all the species studied here if grown under contamination, but also by $\mathrm{Pb}$ in Rumex in common agricultural soil and roadsides. The distance from the road greatly affects contamination, the greatest risk generally being within a range of $5 \mathrm{~m}$ [50].

\section{Conclusions}

Metal contamination is currently a major problem in many agricultural and natural ecosystems, and phytomanagement may represent a suitable, low-cost, green technology option compared with more invasive physical and chemical methods of decontamination. Species choice among wild alimurgic plants creates new opportunities for phytoextraction and possibly in planta stabilisation in the medium-term, mainly of $\mathrm{Zn}$ and $\mathrm{Cu}$. Bioavailable contaminant stripping seems to be the most efficient process, also for reducing metal movements and ground-water contamination, although with some limitations due to modest biomass yield and the alkaline $\mathrm{pH}$ of several soils, which reduces metal uptake. Compared with biomass crops, there is considerable scope for improving phytoremediation with these species, in view of their efficient metal accumulation and adaptability to extreme soil and climatic conditions (e.g., waterlogging, drought, nutrient deficiencies). The absence of any significant diseases and their polyannual growth also guarantee the maintenance of a stable vegetation cover, which can maximise benefits when a community of species is used. Stakeholders and authorities should consider the opportunity to favour natural re-vegetation of critical environments, such as mining areas or landfills, where water drift and wind erosion facilitate metal dispersion from bare soil.

Plant collection for food uses should not be recommended in critical environments, particularly roadsides, as these areas are easily contaminated by $\mathrm{Cd}$ and $\mathrm{Pb}$. Clearly, this fact should be assessed over the whole dietary metal intake and considering metal losses deriving from ion leakage during boiling, to estimate total daily intake. At the regulatory level, there is much debate on the use of total and/or bioavailable metal abundances to define soil safety, but their true roles in plant metal accumulation are uncertain, due to other soil features such as soil $\mathrm{pH}$, organic matter content, oxidation, etc., which affect element mobility.

Acknowledgments: The Italian Ministry of Instruction, University and Scientific Research (MIUR) is gratefully acknowledged for financial support (PRIN 2008, Research Project of National Interest), project "Phytostabilisation of metal-polluted lands with agrarian species". The authors wish to thank Maria Clara Zuin for providing the seeds for the pot trials. Gabriel Walton is also thanked for revision of the English text. 
Author Contributions: Marianna Bandiera: collecting and analyzing the data; writing the first draft of manuscript. Cristian Dal Cortivo: collecting and analyzing the data. Giuseppe Barion: assisted with statistical analysis. Giuliano Mosca: helping in designing the research. Teofilo Vamerali: conceptualizing the research idea; lead author. All authors contributed to the interpretation and discussion of the results.

Conflicts of Interest: The authors declare no conflict of interest.

\section{References}

1. Counter, S.A.; Buchanan, L.H.; Ortega, F. Neurocognitive screening of lead-exposed Andean adolescents and young adults. J. Toxicol. Environ. Health A 2009, 72, 625-632. [CrossRef] [PubMed]

2. Naja, G.M.; Volesky, B. Toxicity and sources of $\mathrm{Pb}, \mathrm{Cd}, \mathrm{Hg}, \mathrm{Cr}$, As, and radionuclides in the environment. In Heavy Metals in the Environment; Wang, L.K., Chen, J.P., Hung, Y., Shammas, N.K., Eds.; CRC Press: Boca Raton, FL, USA, 2009; pp. 13-61.

3. García-Lestón, J.; Roma-Torres, J.; Mayan, O.; Schroecksnadel, S.; Fuchs, D.; Moreira, A.O.; Pásaro, E.; Méndez, J.; Teixeira, J.P.; Laffon, B. Assessment of immunotoxicity parameters in individuals occupationally exposed to lead. J. Toxicol. Environ. Health A 2012, 75, 807-818. [CrossRef] [PubMed]

4. Satarug, S.; Haswell-Elkins, M.R.; Moore, M.R. Safe levels of cadmium intake to prevent renal toxicity in human subjects. Br. J. Nutr. 2000, 84, 791-802. [PubMed]

5. Joseph, P. Mechanisms of cadmium carcinogenesis. Toxicol. Appl. Pharmacol. 2009, 238, 272-279. [CrossRef] [PubMed]

6. Erdman, J.W., Jr.; MacDonald, I.A.; Zeisel, S.H. Present Knowledge in Nutrition, 10th ed.; Wiley-Blackwell: New York, NY, USA, 2012.

7. Jomova, Y.; Valko, M. Advances in metal-induced oxidative stress and human disease. Toxicology 2011, 283, 65-87. [CrossRef] [PubMed]

8. Chen, Z.; Meng, H.; Xing, G.; Chen, C.; Zhao, Y.; Jia, G.; Wang, T.; Yuan, H.; Ye, C.; Zhao, F.; et al. Acute toxicological effects of copper nanoparticles in vivo. Toxicol. Lett. 2006, 163, 109-120. [CrossRef] [PubMed]

9. Nriagu, J. Zinc toxicity in humans. In Encyclopedia of Environmental Health; Nriagu, J., Ed.; Elsevier B.V.: Amsterdam, NL, The Netherlands, 2007; pp. 1-7.

10. Tapiero, H.; Townsend, D.M.; Tew, K.D. Trace elements in human physiology and pathology. Copper. Biomed. Pharmacother. 2003, 57, 386-398. [CrossRef]

11. Robinson, B.H.; Bañuelos, G.; Conesa, H.M.; Evangelou, M.W.H.; Schulin, R. The phytomanagement of trace elements in soil. Crit. Rev. Plant Sci. 2009, 28, 240-266. [CrossRef]

12. Vamerali, T.; Marchiol, L.; Bandiera, M.; Fellet, G.; Dickinson, N.M.; Lucchini, P.; Mosca, G.; Zerbi, G. Advances in agronomic management of phytoremediation: Methods and results from a 10-year study of metal-polluted soils. Ital. J. Agron. 2012, 7, 323-330. [CrossRef]

13. Palmgren, M.G.; Clemens, S.; Williams, L.E.; Kramer, U.; Borg, S.; Schjorring, J.K.; Sanders, D. Zinc biofortification of cereals: Problems and solutions. Trends Plant Sci. 2008, 13, 464-473. [CrossRef] [PubMed]

14. White, P.J.; Broadley, M.R. Biofortification of crops with seven mineral elements often lacking in human diets-Iron, zinc, copper, calcium, magnesium, selenium and iodine. New Phytol. 2009, 182, 49-84. [CrossRef] [PubMed]

15. Baker, A.J.M.; Brooks, R.R. Terrestrial higher plants which hyperaccumulate metallic elements-A review of their distribution; ecology and phytochemistry. Biorecovery 1989, 1, 81-126.

16. Barrutia, O.; Epelde, L.; García-Plazaola, J.I.; Garbisu, C.; Becerril, J.M. Phytoextraction potential of two Rumex acetosa L. accessions collected from metalliferous and non-metalliferous sites: Effect of fertilization. Chemosphere 2009, 74, 259-264. [CrossRef] [PubMed]

17. Bech, J.; Duran, P.; Roca, N.; Poma, W.; Sánchez, I.; Barceló, J.; Boluda, R.; Roca-Pérez, L.; Poschenrieder, C. Shoot accumulation of several trace elements in native plant species from contaminated soils in the Peruvian Andes. J. Geochem. Explor. 2012, 113, 106-111. [CrossRef]

18. Martin, H.W.; Young, T.R.; Kaplan, D.I.; Simon, L.; Adriano, D.C. Evaluation of three herbaceous index plant species for bioavailability of soil cadmium; chromium; nickel and vanadium. Plant Soil 1996, 182, $199-207$.

19. Maria do Rosário, G.O.; van Noordwijk, M.; Gaze, S.R.; Brouwer, G.; Bona, S.; Mosca, G.; Hairiah, H.K. Auger sampling, ingrowth cores and pinboard methods. In Root Methods-A Handbook; Smit, A.L., Bengough, A.G., Engels, C., van Noordwijk, M., Pellerin, S., van de Geijn, S.C., Eds.; Springer: Berlin, Germany, 2000; pp. 175-210. 
20. Vamerali, T.; Guarise, M.; Ganis, A.; Bona, S.; Mosca, G. Analysis of root images from auger sampling with a fast procedure: A case of application to sugar beet. Plant Soil 2003, 255, 387-397. [CrossRef]

21. US Environmental Protection Agency (USEPA). EPA method 3051, microwave assisted acid digestion of sediments; sludges; soils; and oils. Test Methods for Evaluating Solid Waste, 3rd ed.; USEPA: Washington, DC, USA, 1995.

22. Lindsay, W.L.; Norvell, W.A. Development of a DTPA soil test for zinc, iron, manganese and copper. Soil. Sci. Soc. Am. J. 1978, 42, 421-428. [CrossRef]

23. US Environmental Protection Agency (USEPA). EPA Method 3052; microwave assisted acid digestion of siliceous and organically based matrices. Test Methods for Evaluating Solid Waste, 3rd ed.; USEPA: Washington, DC, USA, 1995.

24. Keane, B.; Collier, M.H.; Shann, J.R.; Rogstad, S.H. Metal content of dandelion (Taraxacum officinale) leaves in relation to soil contamination and airborne particulate matter. Sci. Total Environ. 2001, 281, 63-78. [CrossRef]

25. Malizia, D.; Giuliano, A.; Ortaggi, G.; Masotti, A. Common plants as alternative analytical tools to monitor heavy metals in soil. Chem. Cen. J. 2012, 6, 1-10. [CrossRef] [PubMed]

26. Radulescu, C.; Stihi, C.; Barbes, L.; Chilian, A.; Chelarescu, D.E. Studies concerning heavy metals accumulation of Carduus nutans L. and Taraxacum officinale as potential soil bioindicator species. Rev. Chim.-Buchar. 2013, 64, 754-760.

27. Simon, L.; Martin, H.W.; Adriano, D.C. Chicory (Cichorium intybus L.) and dandelion (Taraxacum officinale Web.) as phytoindicators of cadmium contamination. Water Air Soil Pollut. 1996, 91, 351-362. [CrossRef]

28. Liao, M.T.; Hedley, M.J.; Woolley, D.J.; Brooks, R.R.; Nichols, M.A. Copper uptake and translocation in chicory (Cichorium intybus L. cv. Grasslands Puna) and tomato (Lycopersicon esculentum Mill. cv. Rondy) plants grown in NFT system. I. Copper uptake and distribution in plants. Plant Soil 2000, 221, 135-142. [CrossRef]

29. Aksoy, A. Chicory (Cichorium intybus L.): A possible biomonitor of metal pollution. Pak. J. Bot. 2008, 40, 791-797.

30. Del Río-Celestino, M.; Font, R.; Moreno-Rojas, R.; De Haro-Bailón, A. Uptake of lead and zinc by wild plants growing on contaminated soils. Ind. Crop. Prod. 2006, 24, 230-237. [CrossRef]

31. Xiong, Z.T. Bioaccumulation and physiological effects of excess lead in a roadside pioneer species Sonchus oleraceus L. Environ. Pollut. 1997, 97, 275-279. [CrossRef]

32. Wang, Q.R.; Cui, Y.S.; Liu, X.; Dong, Y.T.; Christie, P. Soil contamination and plant uptake of heavy metals at polluted sites in China. J. Environ. Sci. Health A 2003, 38, 823-838. [CrossRef]

33. Ernst, W.H.O.; Knolle, F.; Kratz, S.; Schnug, E. Aspects of ecotoxicology of heavy metals in the Harz region-A guided excursion. Lanbauforsch. Völk. 2004, 54, 53-71.

34. Zhao, L.; Yuan, L.; Wang, Z.; Lei, T.; Yin, X. Phytoremediation of zinc-contaminated soil and zinc-biofortification for human nutrition. In Phytoremediation and Biofortification. Two Sides of One Coin; Yin, X., Yuan, L., Eds.; Springer: New York, NY, USA, 2012; pp. 33-57.

35. Vamerali, T.; Bandiera, M.; Lucchini, P.; Dickinson, N.M.; Mosca, G. Long-term phytomanagement of metal-contaminated land with field crops: Integrated remediation and biofortification. Eur. J. Agr. 2014, 53, 56-66. [CrossRef]

36. Bandiera, M.; Mosca, G.; Vamerali, T. Humic acids affect root characteristics of fodder radish (Raphanus sativus L. var. oleiformis Pers.) in metal-polluted wastes. Desalination 2009, 247, 79-92.

37. Marchiol, L.; Fellet, G.; Perosa, D.; Zerbi, G. Removal of trace metals by Sorghum bicolor and Helianthus annuus in a site polluted by industrial wastes: A field experience. Plant Physiol. Biochem. 2007, 45, 379-387. [CrossRef] [PubMed]

38. Vamerali, T.; Bandiera, M.; Coletto, L.; Zanetti, F.; Dickinson, N.M.; Mosca, G. Phytoremediation trials on metal- and arsenic-contaminated pyrite wastes (Torviscosa; Italy). Environ. Pollut. 2009, 157, 887-894. [CrossRef] [PubMed]

39. Vamerali, T.; Bandiera, M.; Mosca, G. In situ phytoremediation of arsenic- and metal-polluted pyrite waste with field crops: Effects of soil management. Chemosphere 2011, 83, 1241-1248. [PubMed]

40. Kabata-Pendias, A.; Pendias, H. Trace Elements in Soils, 3rd ed.; CRC Press: Boca Raton, FL, USA, 2001.

41. Bandiera, M.; Mosca, G.; Vamerali, T. Phytotoxicity and metal leaching in EDDS-assisted phytoextraction from pyrite wastes with Ethiopian mustard and fodder radish. Plant Biosyst. 2010, 144, 490-498. [CrossRef] 
42. Cotter-Howells, J.D.; Caporn, S.J. Remediation of contaminated land by formation of heavy metal phosphates. Appl. Geochem. 1996, 11, 335-342. [CrossRef]

43. Dong, J.; Mao, W.H.; Zhang, G.P.; Wu, F.B.; Cai, Y. Root excretion and plant tolerance to cadmium toxicity-A review. Plant Soil Environ. 2007, 53, 193-200.

44. Tangahu, B.V.; Abdullah, S.R.S.; Basri, H.; Idris, M.; Anuar, N.; Mukhlisin, M. A review on heavy metals (As, $\mathrm{Pb}$, and $\mathrm{Hg}$ ) uptake by plants through phytoremediation. Int. J. Chem. Eng. 2011, 2011, 1-31. [CrossRef]

45. Huang, B.; Xin, J.; Dai, H.; Liu, A.; Zhou, W.; Yi, Y.; Liao, K. Root morphological responses of three hot pepper cultivars to $\mathrm{Cd}$ exposure and their correlations with $\mathrm{Cd}$ accumulation. Environ. Sci. Poll. Res. 2015, 22, 1151-1159. [CrossRef] [PubMed]

46. Verkleij, J.A.C.; Golan-Goldhirsh, A.; Antosiewisz, D.M.; Schwitzguébel, J.P.; Schröder, P. Dualities in plant tolerance to pollutants and their uptake and translocation to the upper plant parts. Environ. Exp. Bot. 2009, 67, 10-22. [CrossRef]

47. Robinson, B.H.; Green, S.R.; Chancerel, B.; Mills, T.M.; Clothier, B. Poplar for the phytomanagement of boron contaminated sites. Environ. Pollut. 2007, 150, 225-233. [CrossRef] [PubMed]

48. Naszradi, T.; Badacsonyi, A.; Németh, N.; Tuba, Z.; Batiĉ, F. Zinc, lead and cadmium content in meadow plants and mosses along the M3 motorway (Hungary). J. Atmos. Chem. 2004, 49, 593-603. [CrossRef]

49. WHO. WHO Guidelines for Assessing Quality of Herbal Medicines with Reference to Contaminants and Residues. Available online: http://apps.who.int/medicinedocs/documents/s14878e/s14878e.pdf (accessed on 7 April 2016).

50. Jankowski, K.; Ciepiela, A.G.; Jankowska, J.; Szulc, W.; Kolczarek, R.; Sosnowski, J.; Wiśniewska-Kadżajan, B.; Malinowska, E.; Radzka, E.; Czeluściński, W.; et al. Content of lead and cadmium in aboveground plant organs of grasses growing on the areas adjacent to a route of big traffic. Environ. Sci. Pollut. Res. 2015, 22, 978-987. [CrossRef] [PubMed]

(C) 2016 by the authors; licensee MDPI, Basel, Switzerland. This article is an open access article distributed under the terms and conditions of the Creative Commons Attribution (CC-BY) license (http://creativecommons.org/licenses/by/4.0/). 